\title{
Source of IPOs' Underperformance - Evidence on the Implication of Accrual Reversal
}

\author{
Qianyun Huang \\ ${ }^{1}$ Queens College - City University of New York, Queens, New York, USA \\ Correspondence: Qianyun Huang, Queens College - City University of New York, Queens, New York, USA. Tel: 1- \\ 718-997-5037. E-mail: Qianyun.huang@qc.cuny.edu
}

Received: July 6, 2016

Accepted: July 29, 2016

Online Published: August 8, 2016

doi:10.5430/afr.v5n3p161

URL: http://dx.doi.org/10.5430/afr.v5n3p161

\begin{abstract}
IPOs' long-run underperformance has been well documented in prior studies. This paper examines earnings management and the implication of accrual reversals as the source of IPOs' underperformance. I decompose earnings reported at the time of IPOs into accrual and cash components. I find that for US IPOs, only the cash component of earnings (not the accrual component) has significant predictive power for future stock performance; suggesting the level of accruals that makes up IPO earnings fails to sustain its performance in the post-issue period. For ADR IPOs, both the accrual and the cash components have significant predictive power for future stock performance. I further investigate whether the level of accrual reversal is associated with stock return in the post-issue period after controlling for earnings change. In the period subsequent to IPOs, after controlling for earnings change, I find that for US IPOs the larger the accrual reversal, the lower the stock performance. This result suggests that IPOs with inflated earnings are over-valued at the time of first going public. In the subsequent periods when accrual reversed against earnings, market penalizes firms with accrual reversal by revising their price valuation. For ADR firms, there is no significant association between accrual reversal and stock returns after controlling for earnings change, suggesting any change in accruals is due to changes in firm performance.
\end{abstract}

Keywords: ADR, Accrual Reversal, Earnings Management, IPO

\section{Introduction}

The work by Ritter (1991) on the long-run performance of Initial Public Offerings (IPOs) first documents, on average, that IPOs substantially underperform the market over a three-year holding period after the issue. Since then, numerous studies have attempted to provide explanations for this anomaly. One explanation is that investors are overly optimistic about the earnings reported at the time of issue and the future performance of the IPOs. This paper will focus on two possible sources for investor over-optimism: window dressing prior to the IPO (earnings management) and the timing of the IPO. While these two elements do not have to be mutually exclusive, they have different implications on future earnings and stock performance.

To distinguish the two sources for investor over-optimism, I use Sloan's (1996) model to decompose earnings into an accrual and cash flow components. I argue that if earnings are managed at the time of IPO, then the accrual component should have low predictive power for future stock performance. On the other hand, if IPO issues are strategically timed to coincide with periods when firms have traditionally experienced abnormally high performance, both the accrual and the cash components (in other words, earnings as a whole) should have low predictive power for future returns.

I also examine the implication on future earning in cases I find evidence of earnings management at the time of IPOs. Specifically, I investigate whether accrual reversal in the periods after IPOs is associated with post-issue performance after controlling for the change in earnings performance. The underlying intuition is that if earnings at the time of IPO are artificially inflated by borrowing accruals from the future period's earnings, the accrual component of earnings is likely to reverse in the periods after IPOs. Therefore, after controlling for the change in earnings performance, any observed association between accrual reversal in the periods after IPOs and IPO's post-issue performance is consistent with the idea that investors recognized the reversing nature of accruals and adjust their stock valuation accordingly. Furthermore, this association is consistent with earnings management as a source of investor over-optimism at the time of IPOs. On the other hand, if earnings management is not a source of investor 
over-optimism, accrual reversal should have little or no association with stock performance after controlling for earnings change.

I further investigate the difference between US IPOs and ADR IPOs with respect to the level of accrual at the time of the IPOs, accrual reversal in subsequent periods, and associations between accruals and stock performance. There are several reasons why US IPOs and ADR IPOs may be different in these respects. First, most ADR firms are brand leaders in their home markets. They are relatively larger in size and tend to be more seasoned firms. Second, in order to be listed in the US, ADR firms are subject to strict listing requirements imposed by the Security Exchange Commission (SEC) and US exchanges. Most importantly, since most ADR firms are already public firms in their home countries, accounting information from the periods prior to IPO issue is available. In comparison, US IPO firms are only required to provide accounting information for the two years prior to the issues. These unique institutional characteristics of ADR firms suggest that they have relatively less incentive and less opportunity to manage earnings at the time of IPOs. I further investigate this question in the study.

The remainder of the paper is organized as follows: Section 2 reviews literature on IPOs' long-run performance, and provides background on earning management using accruals. Section 3 presents sample selection and research design. Results are discussed in Section 4. Section 5 concludes the study.

\section{Literature Review and Institutional Background}

Going public enable firms to secure more capital to expand their operation, however empirical studies have shown that going public may negatively affect the value of the firm's stocks in the short run (Ansari and Riasi, 2016).

\subsection{IPOs Long-run Performance}

Several studies provide empirical evidence showing that IPOs' stock market performance is significantly lower than their benchmarks during the post-issue period (ranging from 3 to 5 years). For example, Ritter (1991) shows the average 3-year holding period return for a sample of IPOs is $34.47 \%$ in compared to $61.86 \%$ return of a sample of control firms matched by industry and market value. Loughran and Ritter (1995) suggest that the post-IPO return underperformance is of economic importance. In their words, "an investor would have had to invest 44 percent more money in the issuers than in nonissuers of the same size to have the same wealth five years after the offering date." The finding of post-IPO underperformance anomaly is robust to different return specifications, such as buy and hold returns and cumulative average adjusted returns (CAR), measured using various benchmarks (for example, market return, return of a control firms sample, and Fama and French's (1993) three-factor model). (Note 1) Furthermore, this anomaly is not unique to the US IPO market. As summarized in Ritter (1998), evidence of post-IPOs underperformance is also found in international stock markets including: Australia, Austria, Brazil, Canada, Chile, Finland, Germany, Japan, Korea, Singapore, Sweden, and the U.K.

Another stream of literature examines IPOs' operating performance during the post-issue period. Using the change in operating income and operation cash flow (deflated by total assets) as measures for operating performance, Jain and Kini (1994) show the decline in operating performance relative to the pre-issue levels for IPOs (both before and after adjustment for industry effects). Furthermore, they document a positive association between managerial ownership retention and measures of operating performance. They suggest this observed association is consistent with both the agency hypothesis and the signal hypothesis in the context of IPO post-issue performance. Specifically, the agency hypothesis suggests managers are less likely to undertake non value-maximizing projects if they retain high ownership in the firm; and the signaling hypothesis suggests that higher ownership retained by managers signals better quality of the firm.

Other explanations for the decline in the post-issue operating performance for IPO firms include managers' window-dressing of accounting numbers (earnings management) prior to the IPO and strategy timing of the IPO. While both explanations are consistent with the idea that investors are over-optimistic at the time of IPO and their initial expectations for performance cannot be sustained in the post-issue period, the two explanations differ in the following respects: First, under the window-dressing explanation, earnings reported at the time of IPO can be artificially inflated by taking positive accruals (borrowing against future periods' earnings). Since earnings and other detail accounting numbers are publicly observable by the market (especially for ADR firms), and assuming the market is efficient; rational investors are not fooled by the manipulation of accounting numbers and prices should correctly reflect the true economic value of the firms. Numerous studies, however, document that managers are successful in affecting stock valuation by inflating earnings numbers. Conversely, under the strategy timing explanation, while reported earnings truly reflect the economic value of the firms at the time of their IPOs, their economic value is at or close to the highest over time. Since a comparison between earnings performance at the time 
or IPOs and pre-IPO earnings is not readily available to outside investors, the future change in the true performance of the firms is difficult to anticipate.

A natural question arises as to whether long-run decline in stock market performance subsequent to the IPOs is related to long-run decline in the operating performance of the IPO firms. More importantly, if decline in stock market performance is related to the firms' operating performance, why is the decline in operating performance not anticipated by the market at the time of the IPOs? In other words, what is the source of the investors' over-optimism that leads to IPOs being overpriced at the time of issue and underperforming in the subsequent periods? Is it managers' window-dressing of reported accounting numbers (earnings management) or strategy timing of IPO issues to a period with unusually good performance?

\subsection{Literature on Earnings Management}

The practice of earnings management is well documented in prior studies. One of the incentives to manage earnings is to affect the valuation of the firm's stock price (the capital market motive), especially prior to capital market transactions such as IPOs. Whether inflated earnings can successfully affect the valuation of the firm's stock price, however, is an empirical question. Prior literature provides evidence supporting both arguments: the market is "fooled" by inflated earnings and that investors understand the implication of earnings management and therefore adjust their valuations accordingly. Since the central question raised in this paper involves whether earnings management occurs at the time of IPO and focuses on the implication of earnings management; the underlying assumption that inflated earnings does affect stock valuation must be applied. This assumption, however, is not without empirical support, as discussed in detail below. (Note 2)

Stein (1989) suggests that current earnings can be inflated at the expense of longer term benefits. He shows that managers tend to behave myopically in that they tend to be more concerned about current share price than worse problems to be occurred in the future. In his model, earnings are inflated by "borrowing" against the next period's earnings at unfavorable implicit rates of interest. Teoh et al. (1998) summarize other methods of earnings management that are consistent with Stein's (1989) model. For example, the accounting method of choice allows the manager to advance the recognition of revenue and delay the recognition of expense to inflate current earnings. Under the percentage-completion method, the revenue of an ongoing project is recognized over time, while under the completed-contract method, revenue is recognized only at project completion. Higher depreciation expense is better recognized in the initial periods using the accelerated depreciation method, rather than the straight-line deprecation method. Managers also have discretion over the timing of asset acquisition and dispositions. Managers can advance gains and delay losses from asset disposition by choosing when to dispose assets. Revenue recognition on sales can also be accelerated or delayed via the timing of merchandise shipment to customers. The above examples of earnings management have no impact on lifetime earnings because of accrual reversal; that is, earnings increases in the current periods will be eventually offset earnings decreases in the future periods.

Defond and Park (2001) and Sloan (1996) both investigate the implications of the accrual reversal effect on earnings and stock performance, but reach different conclusions. Defond and Park (2001) find earnings response coefficients (ERCs) are higher (lower) when abnormal accruals have a decreasing (increasing) effect on earnings. Further, analysts' revisions are associated with the reversal of abnormal accruals. Their findings suggest that the market anticipates the reversing nature of the abnormal accruals. On the contrary, Sloan (1996) finds that "earnings performance attributable to the accrual component of earnings exhibits lower persistence than earnings performance attributable to the cash flow component of earnings." Investors tend to "fixate," however, on reported earnings and fail to recognize the implication of accrual reversals. As a consequence, firms report earnings with relatively high (low) levels of accruals, and experience negative (positive) future abnormal returns. A more recent study by Xie (2001) also provides evidence that the market overestimates the persistence of abnormal accruals and fails to recognize the implications of future earnings.

One of the most related studies to this study on the topic of earnings management at the time of IPO is by Teoch et al. (1998). They suggest that IPO firms mange earnings by adopting discretionary accounting accruals. Investors fail to recognize that reported earnings are inflated relative to actual cash flow, and subsequently assign too high a value to the IPOs at the time of issue. In the post-issue periods, investors revise their valuations as information about the firm's true economic value is revealed by the media, analysts, and subsequent financial statements. Therefore, Teoch, et al. (1998) assert that "the greater the earnings management at the time of offering, the larger the ultimate price correction." In their empirical tests, different components of the accruals are related to various specifications of three-year stock return performance. They find that discretionary accruals are good predictors for subsequent stock performance, confirming their hypothesis. 
The study conducted by Teoch, et al. (1998) is not without limitations. Ball and Shivakumar (2006) suggest the alternative hypothesis that IPO firms have higher financial reporting quality, since more transparent information is demanded by investors to solve the information asymmetry problem they face at the time of IPO. IPOs are subjected to greater monitoring as their financial statements are examined by market monitors such as the boards, corporate lawyers, internal auditors, independent auditors, analysts, rating agencies, and the media. Furthermore, Ball and Shivakumar (2006) point out several reasons why the abnormal accruals estimation used in the Teoch, et al. (1998) study is likely to be biased regarding earnings inflation. One concern is that IPO firms are likely to be under investing in receivables and inventory prior to the issue and frequently adjust their working capital drastically using IPO proceeds. Since Teoch, et al. (1998) apply the Jones model, which measures accruals using changes in accounts receivable and inventory; (Note 3) positive discretionary accruals are likely mis-specified for IPOs sample. Finally, using industry as a benchmark in the calculation of discretionary (abnormal) accruals is questionable, due to the difference in investing strategy of IPOs and other firms in the same industry.

This paper differs from Teoch, et al. (1998) in at several ways. First, Teoch, et al. (1998) investigate whether the degree of earnings management at the time of IPO is associated with future returns. I examine the predictive power of the accrual component of earnings (as compared to the cash component of earnings) for future returns. Examining the predictive power of both the accrual and cash components of earnings allows one to make inferences about the sources of investor optimism: for example, "window-dressing" of accounting numbers or strategic timing of IPOs. Second, I build upon the Teoch, et al. (1998) study by focusing on the implication of earnings management, specifically the degree of accrual reversal, on future stock return performance, controlling for the effects of earnings change. I use the reversing effect on the accrual component of earnings as a measure of earnings management at the time of IPO. Although this measure only captures earnings management using the timing of accruals, it is consistent with Ball and Shivakumar's (2006) idea that IPO firms face litigation and regulatory risk, and therefore, at best, manage earnings by "borrowing" from future periods. In their words, "The resulting litigation and regulatory risk from inflating earnings would be accentuated by the fact that earnings management can only "borrow" earnings from other periods, so its effect are temporary at best: earnings inflation cause subsequent earnings deflation" (Ball and Shivakumar, 2006). Finally, as suggested by Ball and Shivakumar (2006), I examine whether the market monitoring concern prevents IPO firms from managing earnings. I expand the sample found in the Teoch, et al. (1998) study by including ADR IPOs, a group of firms that are subjected to greater market monitoring. I compare results for these two groups.

\section{Development of Research Question}

To sum up the prior discussion, IPO firms tend to underperform their benchmark during the post issue period. I examine two possible reasons for such underperformance: window-dressing of accounting numbers (earnings management) and strategic timing of IPOs. Prior studies provide mixed evidence as to whether or not earnings are managed at the time of IPOs. I argue, however, that if earnings are managed at the time of IPOs, the accrual component of the earnings should have lower predictive power for future stock performance than the cash component of earnings. The underlying intuition is that earnings reported at the time of IPOs can be inflated by taking accruals borrowed against future periods. On the contrary, the cash component of earnings is fixed and therefore less vulnerable to manipulation. Thus, if the accrual component of earnings cannot be sustained during future periods, it should have a lower predictive power for future stock performance than the cash component of earnings. Thus, the first research question investigates:

1a. Is there a significant difference in the predictive power for future stock performance between the accrual component and the cash component of earnings reported at the time of an IPO?

The examination of the first research question also provides an indirect test for whether IPOs are strategically timed to a period of unusually high performance. If strategic timing, rather than earnings management, takes place at the time of IPOs, both the accrual component and the cash component of earnings should have low predictive power for future stock performance.

I further examine the first research question by comparing the difference between US IPOs and ADR IPOs. As suggested by Lenz (2002), foreign firms going public in the US are subject to legal and regulatory consequences. Market monitoring constraints may potentially limit the opportunity for ADR firms to manage earnings. In addition to the limited opportunity for earnings management, ADR firms may also have less incentive to manage earnings. Leuz (2002) suggests increasing visibility and improvement of firms' information environment as reasons (in addition to raising capital) for why ADR firms choose to go public in the US. Lang, et al. (2002) find that analysts following are increased and forecast accuracy is improved for ADR firms after they go public in the US. Therefore, 
in an effort to improve the information environment, ADR firms are likely to provide higher quality accounting information at the time of their IPOs. In other words, ADR firms are less likely to have inflated earnings at the time of IPOs, since they have less incentive and less opportunity to manage earnings. Therefore, in a cross-sectional comparison between US and ADR IPOs, the accrual components should exhibit higher predictive power for future stock performance for ADR firms. The predictive power of the cash component of earnings for future stock performance should be indifferent. Additional questions therefore include:

$1 b$. Is there a significant difference in the predictive power of the accrual component for future stock performance between US and ADR IPOs?

1c. Is there a significant difference in the predict power of the cash component for future stock performance between US and ADR IPOs?

My second research question examines the implications of earnings management, specifically, the accrual reversal effect in future periods. I investigate whether accrual reversal in the periods after IPOs is associated with post-issue, long-run stock performance after controlling for the effects of earnings change. If at the time of IPOs, investors fail to recognize that the accrual component of earnings is overstated and will reverse against future periods' earnings, then the accrual reversal in the periods after IPOs should present a surprise. Consequently, investors revise their price valuations, which in turn leads to low returns in post-issue periods. On the other hand, if earnings are not managed at the time of IPOs, then the level of accrual as a component of earnings should sustain in the post-IPO periods. Therefore, accrual reversal will not be observed, and any reversal in accruals should be only be due to the change in firm performance. In other words, after accounting for the effect of earnings changes on stock returns, the association between accrual reversal and stock returns should be insignificant. Therefore, further research questions are raised:

2a. For US IPOs, is there an association between accrual reversal and the firms' stock performance in the post-issue period?

2b. For ADR IPOs, is there an association between accrual reversal and the firms' stock performance in the post-issue period?

\section{Sample Selection and Research Design}

\subsection{Sample Selection}

My initial sample consisted of a total of 6,024 US and ADR IPOs (obtained from Securities Data Co. (SDC) for 1990 to 2000 . I choose this ten-year period because a relatively large number of firms went public during late 90 's due to the technology sector bubble. For example, only 1,591 firms went public from 2000 to 2007. A drawback, however, is that the result of the tests may not be applicable to other periods, since firms that went public during the technology sector bubble have unique characteristics, such as negative earnings. The total sample consists of 5,584 US IPOs and 440 ADR IPOs. US IPOs had an average offer price of $\$ 11.99$ and ADR IPOs had an average offer price of \$15.45. I eliminated IPOs from the sample if COMPUSTAT financial data for the year of and the year prior to IPOs was not available. I also eliminated IPOs if CRSP stock price data was not available for at least 37 months after the issue date. This elimination controlled for survival bias. My final sample was reduced to 1676 US IPOs and 161 ADR IPOs. Table 1 provides the sample characteristics (Industry and Nation) for my final sample. 
Table 1. Sample by industry and nation

\begin{tabular}{|c|c|c|c|c|c|}
\hline INDUSTRY & Freq & $\%$ & NATION & Freq & $\%$ \\
\hline Agriculture & 6 & $0.33 \%$ & Argentina & 1 & $0.05 \%$ \\
\hline Construction & 10 & $0.54 \%$ & Australia & 2 & $0.11 \%$ \\
\hline Credit Inst. & 1 & $0.05 \%$ & Bahamas & 1 & $0.05 \%$ \\
\hline Electric Service & 6 & $0.33 \%$ & Belgium & 3 & $0.16 \%$ \\
\hline Gas Distribution & 2 & $0.11 \%$ & Bermuda & 2 & $0.11 \%$ \\
\hline Healthcare & 42 & $2.29 \%$ & British Virgi & 1 & $0.05 \%$ \\
\hline Insurance & 10 & $0.54 \%$ & Canada & 17 & $0.93 \%$ \\
\hline Investment Bank & 5 & $0.27 \%$ & Chile & 4 & $0.22 \%$ \\
\hline Leisure & 22 & $1.20 \%$ & China & 7 & $0.38 \%$ \\
\hline Manufacturing & 773 & $42.08 \%$ & Franee & 12 & $0.65 \%$ \\
\hline Mortgage Bank & 1 & $0.05 \%$ & Germany & 3 & $0.16 \%$ \\
\hline Natural Resource & 39 & $2.12 \%$ & Greece & 2 & $0.11 \%$ \\
\hline Oil/Gas Pipeline & 2 & $0.11 \%$ & Hong Kong & 9 & $0.49 \%$ \\
\hline Other Finance & 6 & $0.33 \%$ & Hungary & 1 & $0.05 \%$ \\
\hline Other Services & 16 & $0.87 \%$ & Indonesia & 2 & $0.11 \%$ \\
\hline Pers/Bus/Rep Svc & 504 & $27.44 \%$ & Ireland-Rep & 3 & $0.16 \%$ \\
\hline REIT & 1 & $0.05 \%$ & Israel & 31 & $1.69 \%$ \\
\hline Radio/TV/Telecom & 56 & $3.05 \%$ & Italy & 5 & $0.27 \%$ \\
\hline Real Estate & 4 & $0.22 \%$ & Japan & 1 & $0.05 \%$ \\
\hline Regional Agency & 1 & $0.05 \%$ & Jordan & 1 & $0.05 \%$ \\
\hline Restaurant/Hotel & 37 & $2.01 \%$ & Mexico & 8 & $0.44 \%$ \\
\hline Retail & 128 & $6.97 \%$ & Neth Antilles & 1 & $0.05 \%$ \\
\hline Sanitation & 7 & $0.38 \%$ & Netherlands & 14 & $0.76 \%$ \\
\hline Telephone Commun & 43 & $2.34 \%$ & New Zealand & 2 & $0.11 \%$ \\
\hline Transportation & 52 & $2.83 \%$ & Panama & 1 & $0.05 \%$ \\
\hline Water Supply & 1 & $0.05 \%$ & Peru & 1 & $0.05 \%$ \\
\hline Wholesale & 62 & $3.38 \%$ & Philippines & 1 & $0.05 \%$ \\
\hline \multirow[t]{10}{*}{ Total } & 1837 & $100.00 \%$ & Portugal & 1 & $0.05 \%$ \\
\hline & & & Russian Fed & 1 & $0.05 \%$ \\
\hline & & & Singapore & 4 & $0.22 \%$ \\
\hline & & & Sweden & 3 & $0.16 \%$ \\
\hline & & & Switzerland & 3 & $0.16 \%$ \\
\hline & & & Taiwan & 1 & $0.05 \%$ \\
\hline & & & United Kinado & 11 & $0.60 \%$ \\
\hline & & & United States & 1676 & $91.24 \%$ \\
\hline & & & Venezuela & 1 & $0.05 \%$ \\
\hline & & & Total & 1837 & $100.00 \%$ \\
\hline
\end{tabular}

Table 2 provides sample descriptive statistics, showing the mean, minimum, maximum and standard deviations of total assets, total common shares outstanding, price at fiscal year end, common equity, operating income after depreciation, basic earnings per share (EPS) excluding extraordinary items, offer price, market value, and market to book ratios. The sample was divided into two groups: US IPOs and ADR IPOs. The reported numbers from the fiscal year end financial statement at the year of IPOs. The average market value of equity (total assets) was approximately \$636 million (\$276 million) for US IPOs and \$2,056 million (\$1298 million) for ADR IPOs confirming the prior find that ADR firms tend to be larger in size. The average EPS excluding extraordinary item was negative (\$0.16) for US IPOs. The negative number was not a complete surprise given that many firms go public despite having negative earnings to take advantage of the IPO markets at the late 90's. Conversely, the average EPS for ADR IPOs was \$0.40. 
The average operating income after deprecation for US IPOs (\$16.67 million) and ADR IPOs (\$141.78) were both positive. Operating income was much smaller for US IPOs, suggesting that the ADR IPOs were more seasoned firms with high operating incomes.

Table 2. Desecriptive statistics

\begin{tabular}{lcrrrr}
\hline US IPOs & $\mathrm{N}$ & \multicolumn{1}{c}{ MIN } & \multicolumn{1}{c}{ MAX } & \multicolumn{1}{c}{ MEAN } & \multicolumn{1}{c}{ STD } \\
\hline Assets - Total (MM\$) & 1676 & $\$ 1.00$ & $\$ 23,043.00$ & $\$ 276.01$ & 1294.74 \\
Common Shares Outstanding (MM) & 1670 & 0.13 & 1210.7 & 21.33 & 51.75 \\
Price - Fiscal Year - Close (\$\&c) & 1610 & $\$ 0.34$ & $\$ 341.31$ & $\$ 19.90$ & 25.4 \\
Common Equity - Total (MMS) & 1676 & $\$(1,370.70)$ & $\$ 11,474.00$ & $\$ 111.02$ & 492.8 \\
Operating Income After Deprec. (MMS) & 1676 & $\$(227.45)$ & $\$ 3,988.00$ & $\$ 16.67$ & 133.74 \\
EPS (Basic) - Exclude Extra. Items (\$\&) & 1669 & $\$(44.27)$ & $\$ 10.19$ & $\$(0.16)$ & 2.16 \\
Offer Price & 1676 & $\$ 1.75$ & $\$ 97.00$ & $\$ 12.82$ & 5.83 \\
Market Value of Equity & 1606 & $\$ 2.18$ & $\$ 83,537.96$ & $\$ 635.81$ & 2845.4 \\
Market to Book & 1606 & $\$(647.59)$ & $\$ 115$ & $\$ 5.38$ & 19.85 \\
\hline ADR IPOs & $\mathrm{N}$ & \multicolumn{1}{c}{ MIN } & MAX & MEAN & STD \\
\hline Assets - Total (MMS) & 161 & $\$ 5.30$ & $\$ 44,691.00$ & $\$ 1,297.69$ & 4202.06 \\
Common Shares Outstanding (MM) & 159 & 2.22 & 1212.62 & 68.1 & 154.54 \\
Price - Fiscal Year - Close (S\&c) & 157 & $\$ 1.34$ & $\$ 92.00$ & $\$ 18.79$ & 14.3 \\
Common Equity - Total (MMS) & 161 & $\$(207.87)$ & $\$ 11,700.00$ & $\$ 595.29$ & 1853.97 \\
Operating Income After Deprec. (MMS) & 161 & $\$(303.93)$ & $\$ 5,422.00$ & $\$ 141.78$ & 549.77 \\
EPS (Basic) - Exclude Extra. Items (S\&c) & 161 & $\$(9.93)$ & $\$ 4.84$ & $\$ 0.40$ & 1.65 \\
Offer Price & 161 & $\$ 4.00$ & $\$ 252.89$ & $\$ 16.37$ & 19.85 \\
Market Value of Equity & 155 & $\$ 6.36$ & $\$ 50,020.37$ & $\$ 2,056.01$ & 6273.87 \\
Market to Book & 155 & $\$(39.14)$ & $\$ 31.35$ & $\$ 4.39$ & 6.8 \\
\hline
\end{tabular}

\subsection{Earnings Component Measures}

To test my research questions, using the model in Sloan (1996), I decomposed earnings reported at the year of IPOs into an accrual component and a cash component, as follows:

$$
\text { Accruals }=(\operatorname{chgCA}-\operatorname{chgCASH})-(\operatorname{chgCL}-\operatorname{chgSTD}-\operatorname{chgTP})-\text { Dep }
$$

Where:

chgCA = change in current assets (Compustat data4),

chgCASH $=$ change in cash/cash equivalents (Compustat data1),

chgCL $=$ change in current liability (Compustat data5),

chgSTD = change in debt included in current liabilities (Compustat data34),

chgTP $=$ change in income taxes payable (Compustat data71), and

Dep $=$ depreciation and amortization expense (Compustat data14).

$$
\text { Cash }=\text { Earnings }- \text { Accrual Component }
$$

Where:

Earnings is defined as the operating income after deprecation (Compustat data178).

To control for the size effect, all three key variables (earnings, accrual component, and cash component) are scaled by average total assets (i.e., the average of the beginning balance and the ending balance of total assets).

\subsection{Stock Performance Measure}

I measure long-term stock performance using 36 months market adjusted (using value-weighted market index) cumulative abnormal returns in the post IPOs periods. Following Ritter (1991) the first trading date is defined as 21 trading days after the IPO issue date. Therefore the window I use to measure long-term stock performance is $t+21$ trading days to $t+21$ trading days +36 months, where $t$ is the IPO issue date. The cumulative abnormal return is calculated as the average monthly abnormal return for firm i over the window. The abnormal return is defined as the 
difference between the firms' monthly raw returns and the benchmark returns.

\subsection{Research Design}

The first research question compares the predictive power of the accrual component of earnings for future stock performance to that of the cash component. To examine this research question, I estimate the OLS regression model as follows:

$$
\text { CARi }=\alpha 0+\alpha 1 \text { Accrualsi }+\alpha 2 \text { Cashi }+\varepsilon
$$

Where

$\mathrm{CAR}=36$ month market adjusted cumulative abnormal return,

Accurals $=$ the accrual component of earnings scaled by average total assets,

Cash $=$ the cash component of earnings scaled by average total assets.

The coefficient of Accruals and the coefficient on Cash measure the respective predictive power for future returns. I use F-test to compare the difference between the coefficient of the Accruals $(\alpha 1)$ and the coefficient of Cash $(\alpha 2)$. In the extension of the first test, I include an indictor ( $D=1$ for ADR IPOs and 0 for US IPOs) variable to measure the difference between US IPOs and ADR IPOs as follows:

$$
\mathrm{CARi}=\alpha 0+\alpha 1 \text { Accrualsi }+\alpha 2 \text { Cashi }+\alpha 3 \mathrm{Di}+\alpha 4 \text { Accrualsi } * \mathrm{Di}+\alpha 5 \mathrm{Cashi} * \mathrm{Di}+\varepsilon
$$

The coefficient of the interaction between the indicator variable and Accruals $(\alpha 4)$ estimates the difference between US IPOs and ADR IPOs with respect to the predictive power of the accrual component for future stock performance. A positive coefficient indicates the predictive power of accrual components for future stock performance is stronger for ADR IPOs. The coefficient of the interaction between the indicator variable and Accruals estimates the difference between US and ADR IPOs with respect to the predictive power of the cash component for future stock performance. If this coefficient is insignificantly different from 0 , then there is no significant difference in the predictive power of the cash component for future stock performance between US and ADR IPOs.

The second research question examines whether there is any association between the long-run stock performance and the reversal in accruals. The level accruals reported at the time of IPO are the benchmark or expected level of accruals. The difference between the level of accruals in the subsequent periods and the expected level of accruals is a proxy for accrual reversal. There are two potential problems that need to be addressed. First, a lower level of accrual in the future period is consistent with the idea that earnings are managed by borrowing against future earnings. But at the same time, it is possible that the decrease in accrual is simply the result of the decrease in earnings. On the other hand, a higher level of accrual in future periods does not necessary suggest the opposite, (i.e., delaying the recognition of revenues). It's possible that the level of accrual in the future periods is higher simply due to earning increases. To address this problem, I include change in earnings as a variable to control for the association between stock returns and change in earnings. Therefore, any association between accrual reversal and future stock performance is the incremental effect.

The level of accrual reversal is calculated as the level of accruals in the subsequent periods minus the level of accrual at the time of the IPOs. A negative number thus indicates accrual reversal, and a smaller (more negative) number indicates higher accrual reversal. I first measure the level of accrual reversal for each year of the 36-month (3-year) test window. The one problem is, without detail analysis of the financial data, it is impossible to determine whether accruals are reversed over a number of years or in a single year. In other words, if earnings at the time of IPOs are inflated by borrowing accruals from future periods' earnings, then the period or periods from which the accruals are borrowed cannot be known. The reason is that managers can choose to take a larger loss in a single year or spread that loss out over a few years. To address this problem, I use two measures to capture accrual reversal. The first measure captures the highest level of accrual reversal (smallest change number) over the 3-year window. The second measure takes the average of accrual reversals over the 3 years. To test the research question $2 \mathrm{a}$ and $2 \mathrm{~b}$, I estimate the following regression model separately to for the samples of US and ADR IPOs:

$$
\mathrm{CARi}=\alpha 0+\alpha 1 \text { AccrualReversali }+\alpha 2 \mathrm{ChgEi}+\varepsilon
$$

Where:

$\mathrm{CAR}=36$ month cumulative abnormal return calculated using the market adjusted model

AccuralReversal $=$ the accrual component of earnings scaled by average total assets at $\mathrm{t}+\mathrm{n}$ minus the accrual component of earnings scaled by average total assets at $t$, where $t$ is the issue date of the IPO, $n$ is 1 ) the year when the level of accrual reversal is highest, 2) the average of the 3 year test window. 


\section{Result}

Table 3 shows the mean cumulative abnormal return (CARs) for each group ranked by the level of accrual at the time of IPOs. Rank 1 is the group with the smallest accrual component of earnings, and Rank 5 is the group with the largest accrual component of earnings. I further divide the sample into two groups: one group with positive operating income and another with negative operating income. It's likely that IPOs with inflated earnings concentrate in the positive operating income group. For the full sample with US IPOs and ADR IPOs, there is an observed decreasing pattern in CAR as the level of accruals increases. For example, the CAR for Rank 1 is 0.13 and the CAR for Rank 5 is -0.01 . The same pattern is observed for IPOs with positive operating income sample. For IPOs with negative operating income, the decreasing pattern disappears: Rank 4 has the lowest CAR, while Rank 5 has the highest CAR. Examining US IPOs and ADR IPOs separately, it appears that the observed result is primarily driven by the US IPOs. The observed pattern remains in the US IPOs subset. For ADR IPOs, CAR fluctuates across the five Ranks of accruals.

Table 3. Cumulative abnormal returns (CARs) by ranking of the accrual component of earnings

Panel A. CARs with dividend included

\begin{tabular}{lrrrrr}
\hline Portfolio & Rank 1 & Rank 2 & Rank 3 & Rank 4 & Rank 5 \\
\hline Full Sample & 0.13 & 0.08 & 0.05 & -0.04 & -0.01 \\
Postive operating income & 0.21 & 0.13 & 0.14 & -0.02 & -0.05 \\
Negative operating income & 0.03 & 0.01 & -0.07 & -0.13 & 0.24 \\
\hline US IPOs & 0.17 & 0.06 & 0.06 & -0.05 & -0.01 \\
\hline Postive operating income & 0.28 & 0.15 & 0.14 & -0.03 & -0.05 \\
Negative operating income & 0.04 & -0.06 & -0.04 & -0.11 & 0.22 \\
\hline ADR IPOs & -0.31 & 0.23 & -0.02 & 0.00 & 0.04 \\
\hline Postive operating income & -0.42 & -0.05 & 0.11 & 0.08 & -0.01 \\
Negative operating income & -0.10 & 1.01 & -0.81 & -0.45 & 0.80 \\
\hline
\end{tabular}

Panel B. CARs with dividend excluded

\begin{tabular}{lrrrrr}
\hline Portfolio & Rank 1 & Rank 2 & Rank 3 & Rank 4 & Rank 5 \\
\hline Full Sample & 0.17 & 0.12 & 0.10 & 0.01 & 0.05 \\
Postive operating income & 0.25 & 0.16 & 0.18 & 0.03 & 0.00 \\
Negative operating income & 0.07 & 0.05 & -0.02 & -0.08 & 0.29 \\
\hline US IPOs & 0.21 & 0.11 & 0.10 & 0.00 & 0.04 \\
\hline Postive operating income & 0.32 & 0.19 & 0.18 & 0.02 & 0.00 \\
Negative operating income & 0.08 & -0.01 & 0.00 & -0.06 & 0.27 \\
\hline ADR IPOs & -0.29 & 0.24 & 0.01 & 0.03 & 0.08 \\
\hline Postive operating income & -0.41 & -0.06 & 0.13 & 0.10 & 0.03 \\
Negative operating income & -0.06 & 1.06 & -0.77 & -0.39 & 0.85 \\
\hline
\end{tabular}

* Rank 1 is the group with smallest accruls.

Table 4 presents results from regression analysis examining the first set of research questions (1a). I investigate the predictive power of the accrual component of earnings for future stock performance. If earnings reported at the time of IPOs are inflated by taking positive accruals from future periods, the accruals component of earnings reported at IPOs should have little or no predictive power for stock returns in subsequent periods. The result in Panel A confirms that the accrual component of earnings is insignificant in predicting future stock returns for the full sample and the sample with positive operating income $(t=-0.7$ and -0.03 respectively). This result is consistent with the notion that earnings reported at the time of IPOs are inflated by taking positive accruals from the future periods.

In comparison, the coefficient on the cash component of earnings is 0.28 and 0.74 for the full sample and the sample with positive operating income, respectively. Both are at $95 \%$ level of significance. The results indicate that, on average, a 1 million dollar increase in the cash component of earnings translates to a $0.28(0.74)$ unit increase in cumulative abnormal return for the full sample (sample with positive operating income). As mentioned earlier, this analysis is also an indirect test for strategic timing of IPOs. If IPOs are timed to a period with unusually high performance, both the accrual component and the cash component of earnings should have no predictive power for 
future returns. The result documented suggests otherwise. The F-test comparing the coefficient on the accrual component of earnings $(\alpha 1)$ to the coefficient on the cash component of earnings $(\alpha 2)$ suggests that the difference between the two is significantly different from 0 at $90 \%$ level for the full sample and at $95 \%$ level for the sample with positive operating income respectively. Overall, the finding is consistent with window-dressing at the time of IPOs rather than strategic timing.

Table 4. Regression analysis (1a)

\begin{tabular}{lrrrrr}
\hline & Full Sample & \multicolumn{4}{c}{ Positive Operating Income } \\
\hline & Parameter & \multicolumn{5}{c}{ Parameter } \\
Independent variables & Estimate & t-value & Estimate & t-value \\
\hline Intercept & 0.0445 & 1.56 & -0.01732 & -0.31 \\
Accrual $(\alpha 1)$ & -0.18441 & -0.7 & -0.01487 & -0.03 \\
Cash $(\alpha 2)$ & 0.28047 & $* *$ & 2.3 & $0.74015 \quad * *$ & 2.11 \\
\hline F-test $(\alpha 1$ vs. $\alpha 2)$ & 3.2 & $*$ & & 7.32 & $* * *$ \\
Observations & 1918 & & 1284 & \\
Adjusted R-Square & 0.0026 & & 0.007 & \\
\hline
\end{tabular}

Dependent variable $=$ CARs

I further test if there is any difference in US IPOs and ADR IPOs with respect to their predictive power of the accrual (cash) component for future stock performance by including an indicator variable for ADR firms and two interaction terms: Accrual x D ( $\alpha 4)$ and Cash x D $(\alpha 5)$. The coefficient, $\alpha 4(\alpha 5)$, captures the difference in predictive power of the accrual (cash) component for future stock performance between US IPOs and ADR IPOs. Results from this analysis are shown in Table 5. For testing using the full sample, and the test using the sample with positive operating income, the coefficient on Accruals ( $\alpha 1)$ remains insignificant and the coefficient on Cash $(\alpha 2)$ remains significant. For the test using the full sample, both of the interaction terms are insignificant. An interesting result appears when applying the samples with positive operating income. The coefficient on Accrual x D ( $\alpha 4)$ is positive and significant at the $90 \%$ level. This result implies that for ADR IPOs, the accrual component of earnings have predictive power for stock returns in the post-issue period, and this predictive power is incremental to that of US firms. The coefficient on the interaction term between cash and the indicator $(\alpha 5)$ variable is positive, but insignificant, implying that there is no significant difference in the predictive power of the cash component for future stock return between US IPOs and ADR IPOs.

Table 5. Regression analysis $(1 \mathrm{~b} \& 1 \mathrm{c})$

\begin{tabular}{lrrrrr}
\hline & Full Sample & \multicolumn{3}{c}{ Positive Operating Income } \\
\hline & Parameter & \multicolumn{5}{c}{ Parameter } \\
Independent variables & Estimate & & t-value & Estimate & t-value \\
\hline Intercept & 0.051 & $*$ & 1.72 & 0.01023 & 0.17 \\
Accrual & -0.292 & & -1.08 & -0.27473 & -0.6 \\
Cash & 0.295 & $* *$ & 2.36 & $0.6546 \quad *$ & 1.8 \\
$\mathrm{D}$ & -0.048 & & -0.45 & -0.19078 & -0.97 \\
Accrual * D $(\alpha 4)$ & 1.751 & & 1.62 & $2.7688 \quad *$ & 1.73 \\
Cash * D $(\alpha 5)$ & -0.338 & & -0.55 & 0.45711 & 0.33 \\
\hline F-test $(\alpha 1$ vs. $\alpha 2)$ & 3.2 & $*$ & & 4.17 & $* *$ \\
Observations & 1918 & & 1284 & \\
Adjusted R-Square & 0.003 & & 0.0095 & \\
\hline
\end{tabular}

Dependent variable $=$ CARs

The second research question examines the association between accrual reversal and stock returns in the post-issue periods ( $2 \mathrm{a} \& 2 \mathrm{~b}$ ). As discussed in the research design section, accrual reversal (AccrualReversal) is calculated using the future period accrual minus the accrual reported at the time of the IPOs. The first proxy I used is the highest accrual reversal in a single year within the 3-year test window, and the second proxy is the average accrual reversal in the 3-year test window. It's important to note that the smaller the test variable (AccrualReversal), the larger is the magnitude of the accrual reversal. Therefore, a positive association between CAR and AccrualReversal would 
actually indicate that stock returns decrease as accrual reversal increases. The control variable, change in earnings (ChgE), is used to control for the association between stock return and changes in earnings. Since accrual is already a component of earnings, it should not have any association with stock returns after earnings change is controlled for. The result in Table 6 indicates otherwise. For US IPOs, the tests using both proxies for accrual reversal show that the coefficient on change in earnings (ChgE) is positive and significant as expected. AccrualReversal, however, is also positive and significant. The results imply that for every 1 unit accrual that is reversed (below the IPOs level), there is $0.617(0.678)$ unit decrease in stock returns for the test using the first (second) proxy for accrual reversal. It appears that the market revises price valuation downwards when accruals go below the IPO level. For the ADR IPOs, earnings change is positively associated with stock returns, as expected. There is no significant association, however, between stock returns and accrual reversal after earnings change is controlled for.

Table 6. Regerssion analysis ( $2 \mathrm{a} \& 2 \mathrm{~b}$ )

Panel A. Highest accrual reversal

\begin{tabular}{|c|c|c|c|c|c|c|}
\hline \multirow[b]{3}{*}{ Independent variables } & \multicolumn{2}{|l|}{ US IPOs } & \multicolumn{4}{|c|}{ ADR IPOs } \\
\hline & Parameter & & & Parameter & & \\
\hline & Estimate & & t-value & Estimate & & t-value \\
\hline Intercept & 0.17227 & 4.99 & $* * *$ & 0.11157 & & 0.95 \\
\hline Accrual Re ve rsal & 0.61728 & 4.39 & $* * *$ & -0.01661 & & -0.02 \\
\hline ChgE & 0.15183 & 2.43 & $* *$ & 0.74928 & ** & 2.02 \\
\hline Observations & 1672 & & & 158 & & \\
\hline Adjusted R-Square & 0.0258 & & & 0.021 & & \\
\hline
\end{tabular}

Panel B: Average accrual reversal

\begin{tabular}{|c|c|c|c|c|c|c|}
\hline \multirow[b]{3}{*}{ Independent variables } & \multicolumn{2}{|l|}{ US IPOs } & \multicolumn{4}{|c|}{ ADR IPOs } \\
\hline & & & & Parameter & & \\
\hline & Estimate & & t-value & Estimate & & t-value \\
\hline Intercept & 0.14952 & 4.73 & $* * *$ & 0.1075 & & 1.03 \\
\hline Accrual Re ve rsal & 0.57839 & 3.03 & $* * *$ & 0.21197 & & 0.21 \\
\hline ChgE & 0.67849 & 6.31 & $* * *$ & 1.48598 & ** & 2.48 \\
\hline Observations & 1672 & & & 158 & & \\
\hline Adjusted R-Square & 0.0455 & & & 0.031 & & \\
\hline
\end{tabular}

\section{Conclusions}

Prior studies suggest investor over-optimism at the time of IPOs as an explanation for the IPO underperformance anomaly. This study contributes to the literature by examining further the source of investor over-optimism. Specifically, I investigate two sources of investor over optimism: "window-dressing" of accounting numbers and strategic timing of IPOs. I document evidence consistent with "window-dressing" of accounting numbers (not strategic timing) as a source of investor over-optimism for US IPOs. I find that the accrual component of earnings reported at IPOs has no predictive power for subsequent stock returns, and the cash component is positively associated with future stock performance. For ADR IPOs, both the accrual component and the cash component of earnings reported at the time of IPOs have predictive power for future stock performance. I also examine the association between accrual reversal and stock performance in post-issue periods. I find that for US IPOs, the larger the accrual reversal, the lower the stock performance in the periods subsequent to IPOs, after controlling for earnings change. The result suggests IPOs with inflated earnings are overvalued at the time of the issues. In the subsequent periods when accrual reversed against earnings, market penalizes these firms by revising their price valuation. For ADR firms, there is no significant association between accrual reversal and stock returns after controlling for earnings change, suggesting any change in accruals is simply due to the changes in earnings. This finding on the difference between US and ADR IPOs provide a possible avenue for future research to further investigate the reasons for this difference. 


\section{References}

Ansari, A. \& Riasi, A. (2016). Modelling and Evaluating Customer Loyalty Using Neural Networks: Evidence from Startup Insurance Companies. Future Business Journal, 2(1), 15-30. http://dx.doi.org/10.1016/j.fbj.2016.04.001

Ball, Ray \& Shivakumar, Lakshmanan. (2007). Earnings Quality at Initial Public Offerings. Journal of Accounting \& Economics, 45(2-3), 324-349. http://dx.doi.org/10.1016/j.jacceco.2007.12.001

Brav, Alon \& Geczy, Christopher \& Gompers, Paul A. (2000). Is the abnormal return following equity issuances anomalous?. Journal of Financial $\quad$ Economics, $\quad 56(2), \quad 209-249$. http://dx.doi.org/10.1016/S0304-405X(00)00040-4

DeFond, M., Park, C. (2001). The Reversal of Abnormal Accruals and the Market Valuation of Earnings Surprises. The Accounting Review, 76, 75-404. http://dx.doi.org/10.2308/accr.2001.76.3.375

Jain, B. \& O. Kini. (1994). 'The post-issue operating performance of IPO firms'. Journal of Finance, 49, $1699-1726$. http://dx.doi.org/10.1111/j.1540-6261.1994.tb04778.x

Lang, M., J. Raedy, \& M. Yetman. (2002). How Representative Are Cross-Listed Firms? An Analysis of Firm and Accounting Quality, working paper, University of North Carolina, Chapel Hill."

Loughran, T. \& J. Ritter. (1995). 'The new issues puzzle'. Journal of Finance, 50, $23-51$. http://dx.doi.org/10.1111/j.1540-6261.1995.tb05166.x

Ritter, J.R. (1991). The long-run performance of initial public offerings. Journal of Finance, 46, 3-27. http://dx.doi.org/10.1111/j.1540-6261.1991.tb03743.x

Sloan, R.G. (1996). Do Stock Prices Fully Reflect Information in Accruals and Cash Flows about Future Earnings? The Accounting Review, 71 (July1996), 289-316. http://dx.doi.org/10.2469/dig.v27.n1.5

Stein, J. C. (1989). Efficient Capital Markets, Inefficient Firms: A Model Of Myopic Corporate Behavior. The Quarterly Journal of Economics, 104(4), 655-669. http://dx.doi.org/10.2307/2937861

Teoh, Siew Hong, Ivo Welch and T.J. Wong. (1998). Earnings Management and the Long-Run Market Performance of Initial Public Offerings. Journal of Finance, 53(6), 1935-1974. http://dx.doi.org/10.1111/0022-1082.00079

\section{Notes}

Note 1 . While majority of the studies document evidence supporting the post IPO performance anomaly, Brav et al. (2000), however, show that IPOs' post issue returns are not significantly different from a sample of non-issuing control firms matched by size and book-to-market ratio. Further several studies document the problems with estimating long-run returns.

Note 2. See Sloan (1996) and Xia (2001).

Note 3. In the Jones (1991) model, current accruals $=$ Change [accounts receivables + inventory + other current assets] - Change [accounts payable + tax payable + other current liabilities]. 